\title{
Are there tragedies without villains?
}

On recent precedent, the latest crop of defendants in the French contaminated-blood saga will not be given a fair trial; some are already the victims of double-jeopardy.

THE search for criminals to be held responsible for the French contaminated-blood scandal continues (see page 548). Among those now arraigned are M. Laurent Fabius, once President François Mitterrand's prime minister, and M. François Gros, the distinguished cell biologist and government adviser who happened to be the chairman of a crucial committee when the decisions to delay blood treatment and the screening of transfusion-blood were made in 1985. Everybody agrees, of course, that the decisions were wrong. Lives, perhaps hundreds of them, would have been saved if heat treatment and screening had begun earlier. It may also be the case that the decision eventually made was coloured by chauvinism, the preference for French rather than US reagents and techniques. But there are extenuating circumstances galore, of which the chief is the uncertainty at the time about the causation of AIDS and the reliability of the reagents on the market. Yet the trials that may yet be mounted, on charges of poisoning people, are unlikely to be fair.

That, at least, is the sad precedent set in the recent past. It will not be forgotten that four people have already been tried and convicted over the contaminated-blood affair. One of them, Michel Garretta, the former head of the French transfusion service, has spent two of four years in jail, while JeanPierre Allain, once head of research at the service, has only just been released from his term. Both are now to be tried again, but on charges of poisoning rather than of misleading consumers (of blood-clotting factor) by wrongly claiming that their products were safe. But each has already been tried twice; when Allain appealed against the original verdict, the French judicial system responded with a fresh trial, at which the judges could have decided on longer spells in prison.

Both convictions were unjust. Garretta, the head of the transfusion service, was by common consent the administrative head of a newly privatized public service with an incentive not to import supplies. By his own admission (in his defence), he had not kept up with research on AIDS. Allain, by the admission of the prosecution at his trial, had done much to warn Garretta of the dangers of contaminated blood. By the implication of his conviction, his fault was that of not rushing to Le Canard Enchâiné with his suspicions. But both were victims of the then-current climate of opinion and servants of the government whose officials are next in line for trial.

It is an offence against the civility for which France is distinguished that there should now be a fresh set of trials. Nobody should be surprised if observers now conclude that the French judicial system will go on finding defendants for AIDS-related trials until the understandable anger of the relatives of those infected with HIV is stilled. Now that the new trials have been ordained, the best hope is that the court will address the question that really matters - not whether the decision taken in 1985 was right or wrong, but whether it was taken in good faith. If that is not the central question at the trial, France will have only itself to blame if cynicism about its judicial system is further increased. It is no part of the function of the courts to find a villain for every tragedy.

Meanwhile, the indictment of Fabius, two of his quondam ministers and Gros will be regarded with dismay by all those who now offer the French government advice on the conduct of its business, or who otherwise take responsibility for it as ministers. As modern technology goes, even in 1985 the supply of blood products must have seemed a relatively riskfree business. From civil aviation to nuclear power to biotechnology, there are other areas potentially more prone to danger, real or imagined. Nobody asks that advisers should be free to be irresponsible, but it will serve nobody's interest if they now habitually give ultra-safe advice for fear of otherwise being dragged through the courts when, in good faith, they give the wrong advice and are retrospectively identified as villains.

\section{Plague in India?}

India's recent plague may have been something else, but the need remains to know more of the animal reservoir.

SugGestions from India (see page 547) that the recent outbreak of what seemed pneumonic plague in Gujarat may not have been plague at all may be a great relief for India's tourist industry, but that does not necessarily mean they are incorrect. But it is too soon to be sure. The outbreak of disease in the city of Surat has certainly fallen short of gloomy expectations, but that could be a simple consequence of the speed with which people took avoiding measures. Alternatively, the outbreak may have been caused by an attenuated strain of the plague bacterium, perhaps one adapted to strictly respiratory transmission. Or the people of Gujarat may have a natural immunity. The plan of the World Health Organization (WHO) to mount an investigation in India is a good one. Let us hope that it reports as quickly as intended.

Meanwhile, it is not too soon to ask what the more distant 